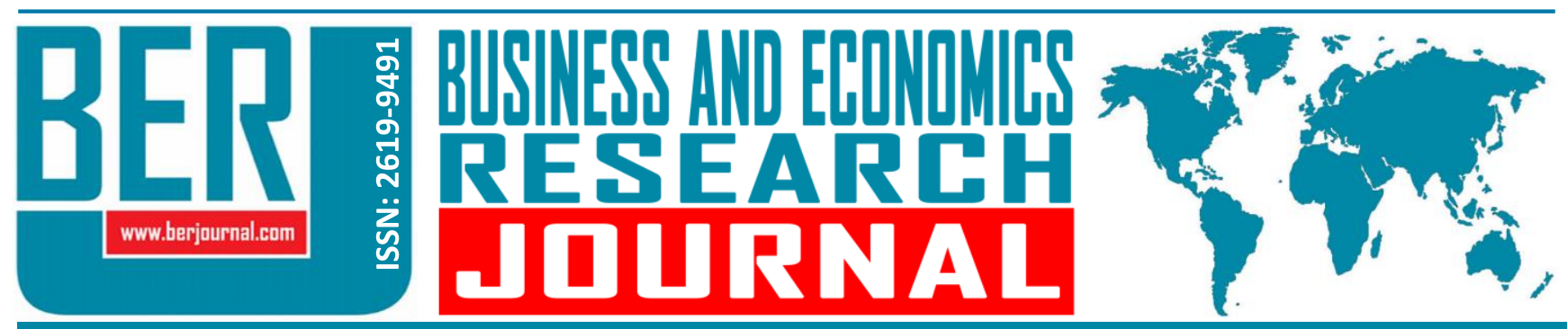

Business and Economics Research Journal Vol. 11, No. 2, 2020, pp. 445-459 doi: 10.20409/berj.2020.260

\section{Değer Akışı Haritalama İle Süreçlerin İyileştirilmesi: Yalın Organizasyonda Bir Vaka Çalışması ${ }^{1}$}

\author{
Hakan Aydin ${ }^{\mathrm{a}}$, Canan Cetin ${ }^{\mathrm{b}}$
}

Öz: Bu çalışmanın amacı, yalın organizasyonda değer akışı haritalama uygulaması ile süreçlerin nasıl iyileştirildiğini açıklamaktır. Değer akışı haritalama, ürün değer akışını görmeye, süreçtekı israf kaynaklarını anlamaya, ürün akışındaki iyileştirme noktalarını fark etmeye ve daha iyi süreçler geliştirmeye yardımcı olmaktadır. Değer akışı haritalama uygulaması, yalın organizasyon olan, değer akışı haritalama konusunda önemli bilgi ve tecrübesi bulunan ve otomotiv sektöründe yer alan XYZ işletmesinde yapılmıştır. XYZ işletmesi, ISO 500'de yer almakta ve 800'den fazla çalışanı bulunmaktadır. Bu çalışmada, değer akışı haritalama tek bir işletme seviyesinde uygulanmıştır. Ürün ailesi olarak seçilen arka koltuğa ilişkin mevcut durum haritası çizilmiş, mevcut durum haritasındaki değer akışı incelenmiş, gelecek durum haritası oluşturulmuş ve gelecek duruma ulaşmak için yapılan iyileştirmeler açıklanmıştır. Sonuç olarak işletmede çalışan sayısının azaldığı, alan tasarrufu sağlandığı, hataların azaldığı, üretim kapasitesinin arttığı, hat duruş zamanının azaldığı, akış süresinin kısaldığı, bitmiş ürün stokunun azaldığı ve üretimin dengelendiği belirlenmiştir. Değer akışı haritalamanın, süreçlerin iyileştirilmesinde önemli bir araç olduğu ve yalın organizasyon olmak isteyen işletmelere önemli faydalar sağlayabileceği değerlendirilmiştir.

\section{Improving Processes Through Value Stream Mapping: A Case Study in Lean Organization}

Abstract: The purpose of this study is to explain how the processes were improved in a lean organization through value stream mapping application. It is suggested that value stream mapping enables to observe product value stream, notice the sources of waste in the process, identify improve-ment points in product flow and develop more efficient processes. The application of value stream mapping was implemented in XYZ company, which is significant knowledge and expe-rience of value stream mapping in the automotive sector. $X Y Z$ company is on the ISO 500 and employs more than 800 employees. In this study value stream mapping was applied on a single company level. The current state map was drawn after selecting rear seat as product family; then the value stream in the current state map was examined, the future state map designed, and improvements explicated to reach a future state. It was concluded that the number of employees in the company decreased, space-saving was realized, defects diminished, produc-tion capacity increased, line stop time decreased, lead time shortened, finished product inven-tory decreased and production was balanced. It is suggested that value stream mapping may be considered as a significant tool in the improvement of processes and providing significant benefits to businesses planning to be lean organizations.
Anahtar Sözcükler: Değer Akışı Haritalama, Süreç İyileştirme, Yalın Organizasyon, Değer, Yalın

JEL: D24, L23, M10

$\begin{array}{ll}\text { Geliş } & : 03 \text { Ocak } 2020 \\ \text { Düzeltme } & : 14 \text { Şubat } 2020 \\ \text { Kabul } & : \text { 12 Mart } 2020 \\ \text { Tür } & : \text { Vaka Çalışması }\end{array}$

Keywords: Value Stream Mapping, Process Improvement, Lean Organization, Value, Lean

JEL: D24, L23, M10

Received : 03 January 2020

Revised : 14 February 2020

Accepted : 12 March 2020

Type : Case Study

a PhD., Istanbul University, School of Business, Business Management and Organization, Istanbul, Turkiye, hakan.aydinn@yahoo.com (ORCID ID:0000-0002-4699-2995)

b Prof., PhD., Marmara University, Retired Faculty Member, Faculty of Business Administration, Istanbul, Turkiye, canancetineylul@gmail.com (ORCID ID: 0000-0002-3498-3346) 


\section{Giriş}

Yalın üretim, müşteri istekleriyle uyumlu ve en az israf ile ürünler geliştirmek için daha az insan emeği, alan, sermaye, malzeme ve zamana ihtiyaç duyulan ürün geliştirme, üretim, tedarikçi ve müşteri ilişkilerinin organize edildiği ve yönetildiği bir iş sistemidir (Marchwinski ve Shook, 2007: 118). Yeni fikirler, daha çok eski fikirlerin artık ihtiyaçları karşılamadığı koşullarda ortaya çıkmaktadır (Womack, Jones ve Ross, 1990: 19). Yalın üretime, Japonya'da müşterinin ihtiyaç ve beklentilerindeki hızlı değişim, kaynakların az olması, pazarın büyük olmaması ve müşteri talebinin az olmasından kaynaklanan, seri üretime uygun olmayan koşullar nedeniyle ihtiyaç duyulmuştur. Yalın üretim, i̇kinci Dünya savaşı sonrasında Toyota'nın rakiplerini incelemesi, onların üretim avantajlarını ve kendi mevcut koşullarını, ülkesinin kültürü ile harmanlaması sonucunda kendi anlayış, yöntem ve tekniklerini geliştirmesi ve bunu sürekli iyileştirmesi sonucunda ortaya çıkmıştır. Yalın üretim sistemi, 1990 'dan sonra tüm dünyada yaygınlaşmaya başlamıştır. Özellikle israfın ortadan kaldırılması ve süreçlerin iyileştirilmesini sağlaması nedeniyle başta üretim işletmeleri olmak üzere tüm sektörlerden çok sayıda işletme yalın olmaya çalışmaktadır (Özçelikel, 1994; Okur, 1997; Womack ve Jones, 2003; Seth ve Gupta, 2005; Abdulmalek ve Rajgopal, 2007).

Yalın üretimin temel yaklaşımı, daha az emek, ekipman, zaman ve alan harcayarak daha fazla üretebilmek ve müşteri beklentilerini daha iyi karşılamaktır (Womack ve Jones, 2003: 15). Bu amaçlara ulaşabilmek için yalın üretim sistemi içerisinde çeşitli teknikler geliştirilmiştir. Yalın tekniklerden kaizen, süreçlerin sürekli iyileştirilmesinde (Imai, 1994); 5S, çalışma ortamlarının daha iyi hale getirilmesinde (Hirano, 1995); tekli dakikalarda kalıp değiştirme (SMED); ürünler arasındaki kalıp değiştirme sürelerinin azaltılmasında (Shingo, 1985); tam zamanında üretim, ihtiyaç duyulan malzemelerin tam zamanında istenilen yerde olmasında (Monden, 2012; Acar, 2003); kanban sistemi, malzeme akışı ve üretiminin düzenlenmesinde kullanılmaktadır (Ohno, 1996). Bu tekniklerden görsel yönetim, sorunların görünür hale getirilmesinde (Imai, 2014); tek parça akışı, süreç odaklı yerleşimden ürünü temel alan yerleşime geçilerek sürekli akışın oluşturulmasında (Suzaki, 2005); heijunka, üretimin dengelenmesinde (Liker, 2005); jidoka, makinaların daha etkili kullanılması ve üretimdeki hataların önlenmesinde (Kitazuka ve Moretti, 2012) ve toplam verimli bakım, makinaların daha verimli hale getirilmesi için kullanılmaktadır (McCarthy ve Rich, 2015). Yalın üretime ait bu teknikler kısaca açıklanmış olmakla birlikte her birinin uygulanması için detaylı planlama, koordinasyon ve eğitim süreci gerekmektedir.

Yalın üretim tekniklerinden değer akışı haritalama, ürün değer akışının görünür hale getirilmesine, değer ve israfın birbirinden ayrılmasına, süreçteki israf kaynaklarının anlaşılmasına, ürün akışındaki iyileştirme noktalarının fark edilmesine ve daha iyi süreçlerin geliştirilmesine yardımcı olmaktadır (Rother ve Shook, 1999). İsrafın azaltılması, kaynakların etkin ve verimli kullanılması, rakipler karşısında fiyat, hız ve kalite konusunda avantaj elde edilmesi ve müşteri yönelimli olmaya katkı sağlamaktadır. Değer akışı haritalama, etkin olmayan süreçlerin ve iyileştirme alanlarının ortaya çıkartılmasında güçlü bir araçtır. Süreçteki çevrim zamanı, akış zamanı, stok miktarı vb. konularda önemli iyileştirmeler sağlamaktadır. Bu çalışmanın amacı, yalın organizasyon uygulaması olan değer akışı haritalama ile işletme süreçlerinin nasıl iyileştirildiğini araştırmaktır. Ayrıca teoride elde edilen bilgilerin uygulamada nasıl gerçekleştiğini ortaya koymak ve yalın olma yönünde ilerleyen uygulayıcılara değer akışı haritalama uygulaması ile katkıda bulunmak amaçlanmıştır.

\section{Kavramsal Çerçeve}

\subsection{Değer ve Değer Akışı}

Değer, problemi çözmek için gerçekten gerekli olan ve bu nedenle müşterinin karşılığını ödediği faaliyettir (Womack ve Jones, 2006: 30). Değer, müşteri tarafından tanımlanır ve üretici tarafından oluşturulur. Müşterinin, süreçten beklentisi değeri tanımlar ve değerin tanımlanması yalın düşüncenin başlangıç noktasıdır (Liker, 2005: 51; Womack ve Jones, 2003: 15). Japonca bir kelime olan muda ise israf demektir, değer yaratmadan kaynakları tüketen faaliyetlerdir (Womack ve Jones, 2003: 15). Yalın düşünce, israfı tespit etmeyi ve ortadan kaldırmayı kolaylaştırmaktadır (Morgan ve Liker, 2007: 92). Değerle ile israfı ayırt edebilmek için müşterinin bakış açısıyla üretim faaliyetlerinin müşteri memnuniyetine etkisi değerlendirilir. Örneğin arabanın sileceklerinin takılı olması, araba kollarının boyanması, montajının yapılması 
değer katan faaliyetlerdir. Bunların dışında ürünün fabrikada sevkiyatı, ambalajlama, kalite kontrol, depolama vb. faaliyetler ise müşteri memnuniyetini etkilemeyen dolayısıyla değer katmayan faaliyetlerdir (Jones ve Womack, 2002: 18).

Değeri anlamak için öncelikle israf olarak kabul edilen işlerin bilinmesi gerekmektedir. İsrafın başlıca kaynakları; fazla üretim, bekleme, gereksiz taşıma, fazla işlem veya yanlış işlem yapma, fazla stoklama, gereksiz hareket ve kusurlardır (Ohno, 1996: 61; Liker, 2005). Fazla üretim, pazarın talep ettiğinden daha fazla mal üretmektir. Bu israf türü ana problemlerin fark edilmesini engellemekte ancak müşteri taleplerine göre makina ve operatörlerin çalışması düzenlenerek (Suzaki, 2005), kanban sistemi (Hines ve Rich, 1997) ve diğer yalın teknikler kullanılarak önlenebilmektedir. Bekleme, çalışanın otomatik bir makinanın çalışmasını izlemesi veya bir sonraki adımı, malzemeyi, parçayı vb. beklemek zorunda kalması veya kullandığı malzemenin tükenmesi, bağlantılı süreçlerdeki gecikmeler, makina arızası vb. nedenlerden dolayı çalışmamasıdır (Liker, 2005). Zaman etkin kullanılmadığında, bekleme israfı olmaktadır (Hines ve Rich, 1997: 48). Gereksiz taşıma, süreçteki işleri uzak mesafelere taşımak, verimsiz nakliye veya malzemelerin gereksiz taşınmasıdır (Liker, 2005). Taşınan malzemeler aynı zamanda hareket halindeki stok olarak görülebilir (Suzaki, 2005: 204). Bu israfı ortadan kaldırmak için, mesafelerin mümkün olduğunca kısaltılması, parçaların geçici olarak taşınmasının önlenmesi (Toyota Otomotiv Sanayi, 2006), yerleşimde, süreçlerin tasarımında, taşıma yöntemlerinde, bina bakımında ve işyeri organizasyonunda iyileştirmeler yapılması gerekmektedir (Suzaki, 2005: 33).

Fazla işlem veya yanlış işlem yapma, parçaları işlemden geçirirken alet yetersizliği veya ürün tasarımındaki eksiklikler gibi nedenlerle verimsiz iş yapılması, gereksiz hareketlerin olması ve hatalı üretim yapılmasıdır (Liker, 2005). Bu israfı önlemek için ürünlerin imalatında boyama, sızdırmazlık ve diğer mevcut süreçlerin gerekliliği tekrar değerlendirilmeli, işlem sayısı azaltılmalı (Suzaki, 2005: 33), poke-yoke veya jidoka kullanılmalıdır (Hines ve Rich, 1997). Fazla stoklama, zamanından önce ve gerekenden fazla üretmektir. Stok, üretim sürecinin tamamında beklemeyi ifade etmektedir. Stok, sermaye dönüşüm hızını ve kârlılığı azaltmaktadır (Okur, 1997). Stokların azaltılması için malzemelerin büyük miktarda satın alınmaması ya da talep edilmemesi, bir sonraki süreçte gerekli olmayan parçaların üretilmemesi, üretimin büyük partiler halinde yapılmaması ve kullanılmayan malzemelerin ortadan kaldırıması sağlanmalıdır (Suzaki, 2005). Gereksiz hareket, çalışanların parça, alet vb. ararken, yanına gidip gelirken veya bir yere götürüp yığarken yaptıkları israf niteliğindeki hareketlerdir (Liker, 2005). İhtiyaç duyulan malzemelerin çalışanın yakınında bulundurulması, düşürme mekanizması vb. uygulamalar gereksiz hareketi azaltmaktadır (Suzaki, 2005). Kusurlar, hatalı parçaların üretimi veya bunların onarılmasıdır. Çalışanların emeğini ve zamanını, onarma, yeniden işleme, ekleme veya yerine yenisini koymak için üretme ve kontrol etme işlemlerine harcaması israf olmaktadır (Liker, 2005). Kusurun müşteriye yansıması, müşteriyle ilişkilerini ve pazar payını olumsuz etkilemektedir (Suzaki, 2005). Değer akışı haritalama, bu israfların tespit edilmesi ve ortadan kaldırılmasını kolaylaştırmaktadır.

Değer akışı, bir ürünün ham maddeden müşterilere sunulmasına kadar geçen süreç içerisinde katma değer yaratan veya yaratmayan tüm faaliyetlerin bütünüdür (Rother ve Shook, 1999:3). Müşteriden gelen bilgilerin işlenmesi ve müşteriye ürünün sunulmasına kadar yapılan ürünü dönüştürmeye yönelik faaliyetleri kapsamaktadır (Marchwinski ve Shook, 2007: 22). Akış düşüncesinin nihai amacı, üretim sürecindeki tüm duraklama ve beklemeleri ortadan kaldırmaktır. Yalın üretimin ilkeleri; müşteri değerinin tanımlanması, değer akışının anlaşılması, akışın geliştirilmesi, çekme sistemi oluşturarak müşterinin talebiyle akışın belirlenmesi ve sürekli olarak mükemmelliğe ulaşmaya çalışmaktır (Womack ve Jones, 2003: 14-29). Bu ilkeler, modern üretim sistemi tasarımının en gelişmiş şekli olarak değerlendirilmektedir. Yalın üretim ilkelerini uygulamak artık bir rekabet avantajı değil, global rekabette hayatta kalmanın önemli bir ön koşulu haline gelmiştir (Matt, 2008: 783). Değer akışı haritalama, organizasyonlardaki yalın ilkelerin uygulanmasını görsel olarak ortaya çıkarmakta ve geliştirilmesine katkı sağlamaktadır. 


\subsection{Değer Akışı Haritalama}

Değer akışı haritalama, Toyota'nın kullandığı "Malzeme ve Bilgi Akışı Haritası” temel alınarak geliştirilmiştir (Rother ve Shook, 1999: 1-3). Değer akışı haritalama; bir ürünü siparişten teslimata hazır hale getirmek için gerekli olan malzeme ve bilgi akışlarının içinde yer aldığı her adımın basit bir diyagramıdır (Marchwinski ve Shook, 2007: 23). Değer akışı haritalama, bir değer akışı için malzeme ve bilgi akışını görsel olarak sunmakta ve süreç iyileştirmede görsel yönetim için önemli bir araç olmaktadır (Tapping ve Shuker, 2003: 55). Değer akışı haritalama, süreçlerin iyileştirilmesinde planlama (Lobo vd., 2018: 490-491), iletişim ve değişim sürecini yönetmek amacıyla kullanılmaktadır (Rother ve Shook, 1999: 9; Lasa vd., 2008: 49). Değer akışı haritalama, üretimdeki tek bir süreçten daha fazlasının görsel olarak gösterilmesine, israf kaynaklarının belirlenmesine, üretim süreçlerine ilişkin ortak bir dilin oluşturulmasına, farklı yalın tekniklerin birleştirilmesine ve bilgi akışı ile malzeme akışı arasındaki ilişkinin gösterilmesine yardımcı olmaktadır (Rother ve Shook, 1999: 4). Üretim sistemi süreçlerinin yeniden tasarlanmasında, değer akışı haritalama tekniğini kullanmanın faydalı olduğu tespit edilmiştir (Lasa vd., 2008: 39). Ayrıca liderin, mevcut durumdan gelecek duruma geçiş sürecinde yeni inanç, davranış ve yeteneklerinin oluştuğu dolayısıyla liderlik etkinliğini geliştirdiği belirlenmiştir (Emiliani ve Stec, 2004: 643).

Değer akışı haritalamaya ilişkin çalışmalar incelendiğinde daha çok vaka çalışması, kavramsal çalışma, model geliştirme ve az sayıda anket tekniği kullanılmıştır (Singh vd., 2011). Yapılan çalışmalarda değer akışı haritalamanın kullanıması ile zamanında teslim oranı ve uptime oranının (makine kullanım oranı) arttığı, kusurlu ürün sayısının (Vinodh vd., 2010), akış süresinin (Grewal, 2008; Lasa vd., 2008; Singh ve Sharma, 2009; Singh vd., 2011; Jasti vd., 2019), kalıp değiştirme süresinin (Grewal, 2008; Singh vd., 2011), çevrim zamanının (Singh vd., 2011; Lacerda vd., 2016), süreç zamanının (Singh ve Sharma, 2009; Seth ve Gupta, 2005; Vinodh vd., 2010), stok miktarının (Seth ve Gupta, 2005; Singh ve Sharma, 2009; Vinodh vd., 2010; Singh vd., 2011) ve çalışan sayısının (Singh ve Sharma, 2009; Singh vd., 2011; Wang vd., 2015; Lacerda vd., 2016) azaltıldığı sonucuna ulaşılmıştır. Ayrıca alan tasarrufu sağlandığı (Matt, 2008), bekleme süreleri (Wang vd., 2015), maliyet ve çevreye etkinin azaltıldığı belirlenmiştir (Rosenbaum vd., 2014). Bununla birlikte değer akışı haritalamanın farklı ürünlerin akışını göstermemesi, israf türlerine yönelik değerlendirme ve görselin olmaması, görsel bilgilerin etkinliği, performans bilgisinin olmaması (Dinis-Carvalho vd., 2018) ve süreçlerin karmaşıklaşması ile birlikte yetersiz kaldığı için eleştirilmektedir (Schmidtke vd., 2014). İşletmelerin, farklı seviyelerdeki süreçleri geliştirmesi, tasarlaması ve yönetmesi gerekmektedir (Sunk vd., 2017). Değer akışı haritalama, süreç yönetimi yönelimi yaklaşımı, sürdürülebilirlik (Sunk vd., 2017), simülasyon (Abdulmalek ve Rajgopal, 2007; Lian ve Landegem, 2007; Wang vd., 2015), özgün durum simülasyonu (Aziz vd., 2017) ve diğer tekniklerle geliştirilmeye devam edilmektedir. Değer akışı haritalama uygulaması, otomotiv (Singh ve Singh, 2013; Lacerda vd., 2016; Jasti vd., 2019), gaz ve benzin (Lobo vd., 2018), motosiklet (Seth ve Gupta, 2005), acil sağlık hizmetleri (Wang, vd., 2015), demiryolu (Singh vd., 2011), yapı (Rosenbaum vd., 2014), gıda (Taylor, 2005) vb. farklı sektörlerde incelenmiştir.

Değer akışı haritalama, dört aşamada gerçekleştirilmektedir. İlk aşamada ürün ailesi seçilir, ikinci aşamada mevcut durum haritası çizilir. Üçüncü aşamada, mevcut durum haritasının değer akışı incelenerek gelecek durum haritası çizilir ve son aşamada gelecek duruma ulaşmak için iş planları oluşturulur ve uygulama gerçekleştirilir. Değer akışı haritalamanın ilk aşamasında, bir ürün ailesi seçilir ve sonrasında değer akışının hangi seviyede yapılacağı belirlenir (Rother ve Shook, 1999). Değer akışı haritalama; süreç, tek işletme, birden fazla işletme ve farkı işletmeleri kapsayacak şekilde farklı seviyelerde yapılmaktadır. Genellikle tek işletme seviyesinden başlanmakta, ihtiyaç halinde işletme süreçleri seviyesine veya işletme dışı seviyeleri kapsayacak şekilde genişletilmektedir (Jones ve Womack, 2002; Rother ve Shook, 1999). Değer akışı haritalamada, müşteriden tedarikçiye doğru ürünün üretim aşamaları takip edilerek akış yönünün tersine doğru hareket edilmektedir. Önemli olan malzeme ve bilgi akışının anlaşılabilir olmasıdır. Değer akışı haritalamada süreçlerin anlaşıması için semboller kullanılmaktadır (Rother ve Shook, 1999). Değer akışı haritalamada kullanılan başlıca semboller Şekil 1'de gösterilmiştir. 
Şekil 1. Değer Akışı Haritalamada Kullanılan Başlıca Semboller

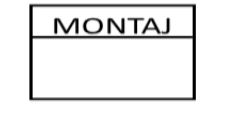

Üretim Prosesi

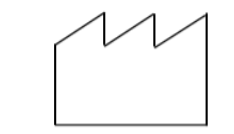

Dış Kaynaklar

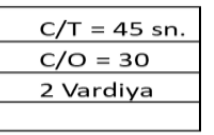

Bilgi Kutusu

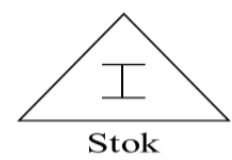

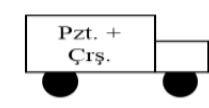

Kamyonla Sevkiyat

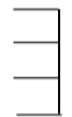

Süpermarket
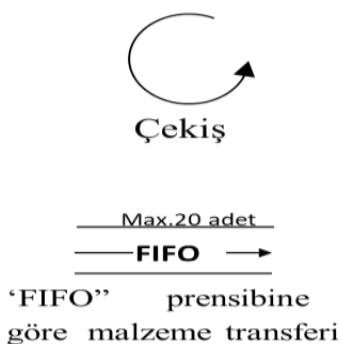

Manuel Bilgi Akışı

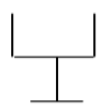

Kanban Kutusu

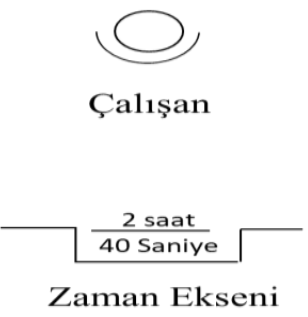

Kaynak: Rother ve Shook, 1999: 16-35.

Mevcut durum haritası çizilirken, öncelikle müşteriye ait bilgilerle başlanmakta, müşteri ve müşteri istekleri gösterilmektedir. Sonrasında işletme süreçleri, süreçlere ilişkin bilgiler ve stok miktarları yazılmaktadır. Değer akışı haritalamada süreçlerin daha iyi anlaşılması ve değerlendirilmesi için bazı ölçütler kullanılmaktadır. Süreç hakkında takt zamanı, çevrim zamanı, akış süresi (lead time), model değiştirme süresi, makine kullanım oranı (uptime), üretim parti büyüklüğü, çalışan sayısı ve diğer ölçütler bilgi olarak gösterilmektedir. Takt, ritim veya metre anlamına gelen Almanca bir kelimedir. Takt zamanı, müşterinin ürünü talep etme hızını ifade etmektedir (Liker, 2005; Seth ve Gupta, 2005). Talep edilen ürünleri, üretmek için belirlenen hedef süredir (Rother ve Shook, 1999). Çevrim zamanı, bir süreçte ürünün tamamlanma sıklığıdır. Ürünün ne kadar sıklıkla üretildiğini ifade etmektedir (Marchwinski ve Shook, 2007). Akış süresi, bir parçanın bir süreç veya değer akışında başlangıçtan bitişe kadar geçen süreyi belirtmektedir. Üçüncü aşamada tedarikçi bilgileri, dördüncü aşamada bilgi akışı gösterilmektedir. Son olarak her işlemin ne kadar zaman aldığını belirten zaman çizelgesi çizilmektedir (Rother ve Shook, 1999). Uygulayıcılar, mevcut durum haritası oluştururken dokümantasyon ve yazılım programlarına güvenilmemesi gerektiğini tavsiye etmektedir (Schmidtke vd., 2014). Mevcut durum haritası oluşturmak için akış boyunca yürüyerek ve görevi uygulayan insanlarla doğrudan görüşerek bilgi ve veri toplanmaktadır (Manos, 2006: 69).

Gelecek durum haritası çizilirken, mevcut durum haritası incelenir ve olası problemler belirlenir (Rother ve Shook, 1999). Seçilen ürün ailesi için takt zamanı hesaplanır. Üretimi bitmiş olan ürünlerin, doğrudan sevkiyata veya sınırlı sayıda ürünün belirli sürede bekletildiği süpermarkete gönderilme durumu belirlenir. Sürekli akışın ve süpermarketin nerede kurulacağı tespit edilir. Üretim sürecinde çizelgelemenin hangi noktadan yapılacağı, hedeflenen üretim sürecinde ürün karmasının nasıl seviyelendirileceği belirlenmektedir. Takt zamanına uygun sürekli akış geliştirilmekte, çekme sistemi kurulmakta, seviyelendirme ve kaizen yapılmaktadır. Gelecek durum haritasına ulaşmak için yapılması gereken faaliyetlere ilişkin iş planı oluşturulmakta ve bu plana uygun olarak uygulamalar gerçekleştirilmektedir.

\section{Araştırmanın Yöntemi}

Araştırma, yalın organizasyon olma konusunda dünyada ve ülkemizde örnek işletmelerden birisi olduğu değerlendirilen, değer akışı haritalamayı iyi uygulayan ve bu konuda önemli tecrübesi olan, otomotiv sektöründeki XYZ işletmesinde yapılmıştır. Otomotiv sektörü, Türkiye'nin en fazla rekabet gücünün olduğu ve en fazla ihracatın yapıldığı sektördür (TIM, 2019). Türkiye'nin en büyük işletmeleri incelendiğinde, otomotiv işletmelerin önde olduğu görülmektedir (ISO 500, 2017). Otomobil koltuğu üretiminde ana işletmelerden biri 
olan XYZ, ISO 500'de yer almakta ve 800'den fazla çalışanı bulunmaktadır. XYZ işletmesi, ABC fabrikasına koltuk ve kapı içi paneli üretmektedir. XYZ işletmesi değer akış haritasını, tüm ürün ve süreçleri kapsayan, "Malzeme ve Bilgi Akış" haritası olarak kullanmaktadır.

İ̧̧letmede öncelikle değer akışı haritasının uygulanacağı ürün ailesi seçilmiş, bu ürüne ilişkin mevcut durum haritası çizilmiş, mevcut durum haritasında olası problemler ve iyileştirme noktaları belirlenmiş, gelecek durum haritası çizilmiş ve yapılan iyileştirme faaliyetleri sonucunda süreçte elde edilen iyileştirmeler belirtilmiştir. Yalın üretim sisteminde müşteri talebine göre üretim yapıldığından bazı veriler talebe göre değişmekte ayrıca işletme bilgilerinin güvenliği nedeniyle bazı bilgiler yaklaşık olarak verilmiştir. Mevcut durum haritasının çizilmesi ile gelecek durum haritasının gerçekleşmesi arasında yaklaşık bir yıl süre geçmiş ve bu süre içerisinde işletmeye çok sayıda ziyaret yapılmıştır. Araştırmacılar, yerinde gözlemleyerek, yönetici ve çalışanlar ile görüşmeler yaparak süreci yakından takip etmiş ve mevcut durum ile gelecek durum değer akış haritalarını çizmişlerdir.

\section{Değer Akışı Haritalama Uygulaması}

Değer akışı haritalama uygulaması için öncelikle iyileştirme yapmaya ihtiyaç duyulan önemli bir ürün seçilmiş, değer akışı haritalama seviyesi belirlenmiş ve bu ürüne ilişkin mevcut durum haritası çizilmiş ve mevcut durum değer akışı ortaya konulmuştur. Bundan sonra mevcut durum haritasında yapılabilecek iyileştirmeler belirlenmiş, gelecek durum haritası oluşturulmuş, planlanan iyileştirmeler yapılmış, mevcut ve gelecek durum değer akışı haritaları değerlendirilerek süreçteki iyileştirmeler açıklanmıştır.

\subsection{Mevcut Durum Haritasının Çizimi}

Değer akışı haritalama uygulamasında, ilk olarak iyileştirme yapılması planlanan önemli bir ürün ailesi seçilmektedir. Bu vaka çalışmasında ürün ailesi olarak $A B C$ marka otomobillerin arka koltuk parçası seçilmiştir. $A$ ve $B$ modellerine göre iki model arka koltuk üretilmekte ve $A B C$ fabrikasına gönderilmektedir. Bu çalışmada, değer akışı haritalama tek bir işletme seviyesinde yapılmıştır. Değer akışı haritasına, mevcut verilerin temini ile başlanmış ve haritalamanın anlaşılabilir olması öncelik olarak değerlendirilmiştir. Mevcut durum haritası oluşturmak için akış boyunca yürüyerek, işi yapan çalışanlar ve yöneticilerle doğrudan görüşerek bilgi ve veriler toplanmıştır. Teslimattan başlayıp, akış yönünün tersine doğru çalışılarak kronometre ile ölçüm yapılmıştır. Mevcut durum değer akış haritasında, önce müşteri bilgileri sonrasında işletme süreçleri ve bu süreçlere ilişkin bilgiler, tedarikçi bilgileri, malzeme ile bilgi akışı ve son olarak arka koltuk üretimine ilişkin akış zamanı belirtilmiştir (Şekil 2).

$X Y Z$ 'nin müşterisi olan $A B C$ işletmesi, haritanın sağ üst köşesinde fabrika sembolü ile gösterilmiştir. Daha sonra bilgi kutusuna $A B C^{\prime}$ nin günlük talebi olan 300 set $A$ modeli ve 400 set $B$ modeli olmak üzere toplam 700 set belirtilmiştir. Bu ürünler $A B C$ işletmesine, takt zamanı olan $85 \mathrm{sn}$. uygun olarak 10'luk setler halinde kamyon ile günde 70 defa gönderilmektedir. Müşteriye ait bu bilgiler yazılarak mevcut durum haritasının ilk aşaması tamamlanmıştır. Haritalamanın ikinci aşamasında, XYZ büyük bir fabrika ikonu ile gösterilmiştir (Şekil 2). Fabrika ikonu, malzemelerin fabrikanın girişinden çıkışına kadar değer akışını ve süreçlerin fabrika içerisindeki yerleşimini göstererek değer akışı haritasının daha anlaşıı olmasını sağlamaktadır. Arka koltuk üretiminin süreçleri olan sevkiyat, A modeli montaj hattı, B modeli montaj hattı, dikiş 1 , dikiş 2 , dikiş 3 , sünger ve kesme süreçlerine ait bilgiler süreç bilgi kutularına yazılmış ve süreçler arasındaki stok miktarları gösterilmiştir. Örneğin A modeli montaj hattında 5 çalışan olduğu, takt zamanının 206 sn., çevrim zamanının 1442 sn., ekipmanların verimli kullanım oranııı \%98 olduğu ve sürecin sonunda 30 set ürünün stok olarak beklediği gösterilmiş̧ir. Mevcut durum haritası, Şekil 2'de sunulmuştur. 
Şekil 2. XYZ İşletmesi Mevcut Durum Haritası

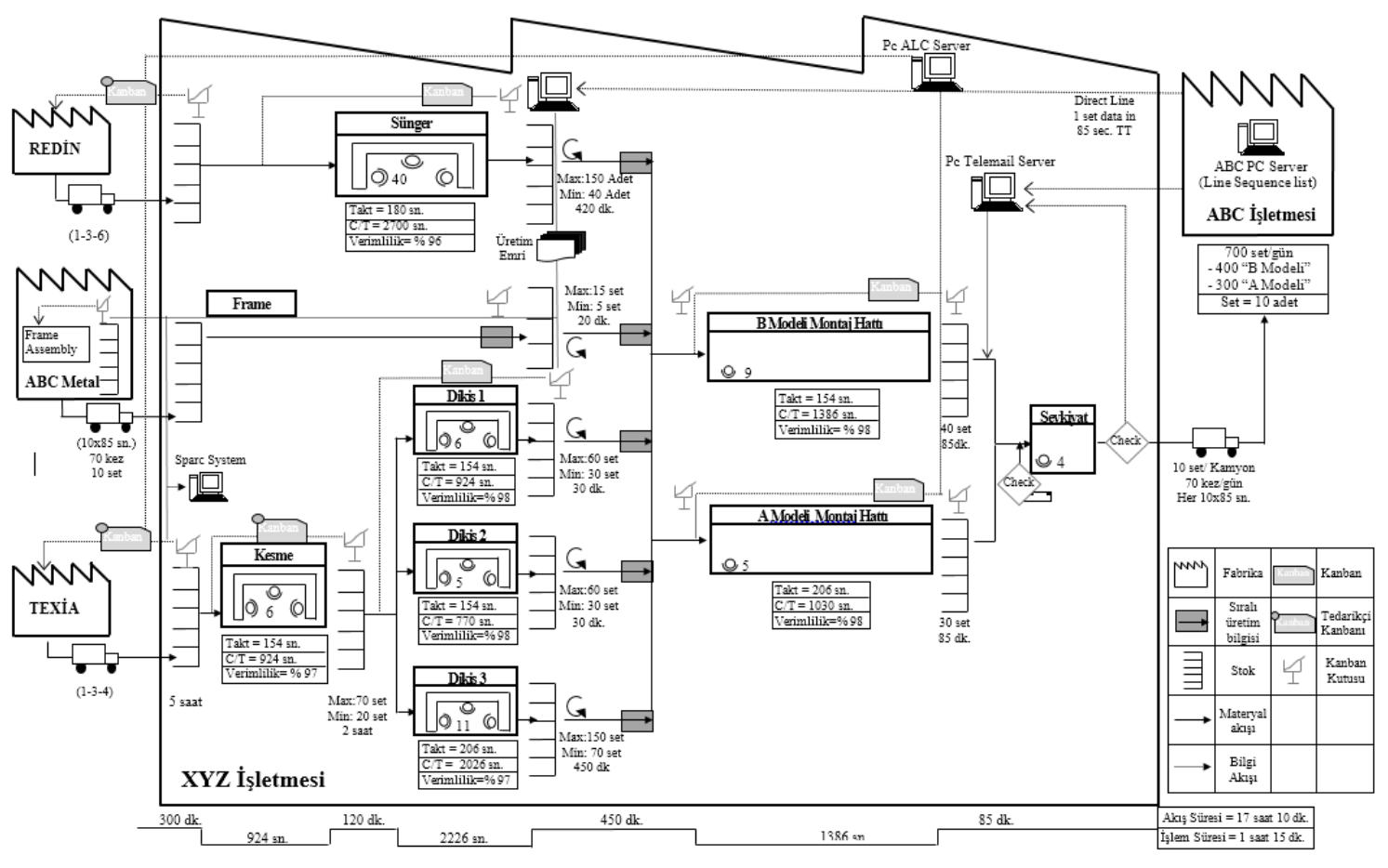

Haritalamanın üçüncü aşamasında haritanın sol üst köşesine XYZ işletmesinin hammaddeyi tedarik ettiği tedarikçi işletmeler ABC Metal, Redin ve Texia fabrika ikonu ile gösterilmiştir. Tedarikçiden malzemenin gelişi için kamyon ikonu kullanılmıştır. Hammaddenin geliş sıklığı ve parti büyüklüğü bilgi kutusunda belirtilmiştir. Örneğin ABC Metal, XYZ işletmesinin takt zamanı olan $85 \mathrm{sn}$. uygun olarak 10'luk setler halinde kamyonla günde 70 defa teslimat yapmaktadır. Burada önemli olan işletmenin teslim ettiği bitmiş ürün miktarı ve zamanı ile tedarik ettiği malzeme miktar ve zamanının dengeli olmasıdır. XYZ işletmesi değer akış haritalamada kanban döngüsünü kullanmaktadır. Örneğin Redin firması (1-2-6) kanban döngüsü kullanarak (gün-kaç kez-kaç sevkiyat sonra) ürünü, bir günde iki kez ve 6 sevkiyat sonra tekrar teslimat yapacağını göstermektedir.

Haritalamanın dördüncü aşamasında bilgi akışı ince çizgi ile gösterilmiştir. Mevcut durumda, $A B C^{\prime}$ nin talep ettiği ürün bilgisini XYZ iki yolla elde etmektedir. XYZ ilk olarak ALC sistemi (assembly line control) ile $A B C^{\prime}$ nin müşterilerinden aldığı sıralı üretim bilgisini ürün ana işletmede üretime başlarken almakta, montaj, dikiş, sünger ve kesme hattına ileterek bu ürünleri $A B C$ ile eş zamanda üretmektedir. $X Y Z$ ikinci olarak, $A B C$ 'nin montaj hattına giren sıralı üretim bilgisi telemail sistemi (üretim bilgisinin online olarak iletildiği sistem) ile XYZ'nin montaj hattının sonuna gelmekte ve bu bilgiye göre sevkiyat yapılmaktadır. Sevkiyat için çalışan sayısı değişim göstermekle birlikte genellikle dört kişi çalışmaktadır. Sevkiyat, telemail bilgisine göre koltukları $A B C^{\prime} y e$ göndermektedir. Gönderilen her ürün ile birlikte o ürünün kanbanı, montaj hattının başına gönderilerek üretim emri verilmektedir. Kanban bilgisine göre çalışanlar yanlarında bulunan küçük parça stoklarından gerekli parçaları alarak üretimi tamamlamaktadır. Tedarikçilere bilgiler, kanban yardımıyla fiziksel olarak gidip gelmektedir. Üretimi yapılacak miktar fazla olduğunda bunun takibini kolaylaştırmak için Sparc sistemi kullanılmaktadır. Bu sistem, tedarikçi kanbanlarının üstündeki bilgileri okumakta ve özet bir liste çıkartarak tedarikçiye göndermektedir. Bu sistemin amacı, kanban hareketlerini takip etmek, hangi üründen ne kadar talep edildiği, ne zaman geleceği vb. bilgileri kontrol altına almaktır. XYZ işletmesinde, süreçler arasında FIFO hatları (ilk giren, ilk çıkar) vardır ve çekme sistemi ile çalışılmaktadır. Ürünler, çıkışta barkod ile kontrol edilmekte, üretim sırası kanban sırasıyla karşılaştırılmakta ve aynı ise gönderilmektedir.

Haritalamanın son aşamasında üretim akış süresi hesaplanmıştır. Bunun için hammaddelerin fabrikaya girişinden, ürün olarak müşteriye teslimatına kadar her sürecin altına stoklar dâhil olmak üzere zaman ekseni çizilmiştir. Zaman eksenine, malzemelerin ilgili aşamada geçen süresi yazılmış ve elde edilen 
değerler toplanarak, üretim akış süresi hesaplanmıştır. XYZ, malzeme ve bilgi akış haritasında, akış süresini kullanmamaktadır. Değer akış haritasında, toplam katma değer yaratan süre ve süreç işlem süreleri ayrı olarak hesaplanmaktadır. Malzemelerin stokta bekleme süreleri, değer katmayan süre olarak belirtilmiştir. Bu çalışmada akış süresi olarak belirlenen 17 saat $10 \mathrm{dk}$., değer katan işlem süresi ve değer katmayan işlem sürelerinin toplanmasıyla hesaplanmıştır. Değer akış haritasının herkes tarafından anlaşılabilmesi için haritanın yanına bazı haritalama sembollerinin açıklaması ilave edilmiştir.

\subsection{Mevcut Durum Değer Akışının Özellikleri}

$\mathrm{XYZ}$ işletmesi, takt zamanına göre üretim yapmakta ve her ürün için takt zamanı ile çalışan sayısı belirlenmektedir. XYZ'nin montaj hattında sürekli akış sistemi vardır. Sürekli akışın olmadığı yerde çekme/FIFO sistemleri bulunmaktadır. Üretim çizelgesi, literatürde sadece bir üretim prosesine gönderilmeli anlayışına karşın XYZ sevkiyat için telemail bilgisini sevkiyata, üretim için ana işletme üretim süreçlerinden aldığı ALC bilgisini kesme, dikiş, sünger ve diğer üretim hatlarına aynı anda göndererek ana işletme ile aynı anda üretim yapmayı planlamakta ancak ana işletmenin üretim hatlarındaki değişikliklerden olumsuz etkilenmektedir. Farklı ürünlerin üretimini zamana düzgün yayma anlayışına karşın XYZ takt zamanına göre üretim yaptığından, yığın bir üretim ve tüketim yapılmamaktadır. Stok miktarları az olduğundan sürekli bir çevrim olmaktadır. XYZ'de kanban kutuları vb. kullanılarak üretim hacmi seviyelendirilmektedir.

$X Y Z$ işletmesinin üretim departmanı, $A B C$ 'nin ihtiyaçlarını daha iyi karşılamaya, üretimde olan değişikliklere daha iyi uyum sağlamaya ve hataları azaltmaya çalışmaktadır. ABC'nin talep miktarı olan 700 set değişim göstermekle beraber bu miktarın değişim süresi çok kısa olmamakta ancak talep miktarındaki modellerin oranı sürekli değişmektedir. Üretim departmanı en önemli sorunun, model miktarındaki değişimin montaj hattını olumsuz etkilemesi olduğunu belirlemiştir. Örneğin, toplam üretim miktarı olan 700 sabitken, A modelinin talep miktarı 300' den 400'e çıktığında A ve B model montaj hattının çalışan sayısı, ekipman, takt zamanı, çevrim zamanı vb. değişmektedir. XYZ işletmesinin mevcut durum haritası incelendiğinde bu değişimden en fazla, üretimin hızını belirleyen montaj hattının etkilendiği ve bu nedenle montaj hattının değişimden daha az etkilenmesi için arka koltuk montaj hattı süreçlerinin iyileştirilerek yeniden düzenlenmesine karar verilmiştir. Yapılan değerlendirmeler sonucunda, üretim miktarındaki değişimler nedeniyle oluşan sorunlar, çalışan ve ekipman ana başlıklarında toplanmıştır. Çalışan ile ilgili olarak, üretim miktarındaki değişim nedeniyle çalışanların yerleri değişmektedir. Model miktarındaki değişime göre kurulan yeni hat düzeninde, yapılacak işin paylaşımı farklılaşmakta ve bu nedenle çalışanın işini en iyi şekilde yapması için değişen iş unsurlarına göre eğitim verilmesi gerekmektedir. Çalışanın montaj hattının yeni düzenine göre üretime başlaması ile kalite kontrol faaliyetleri arttırılmaktadır. XYZ işletmesi, üretim hacminin değişmesi sonucunda ön koltuk hattı dâhil olmak üzere çalışanın toplam 389 saat kaybı olduğunu tespit etmiştir. Ekipman ile ilgili olarak, model miktarındaki değişim nedeniyle montaj hattı değişmektedir. Çalışanların yerlerinin değişmesi ile ekipmanlarında yerleri ve miktarları değişmekte, sonuç olarak ekipmanların yeniden etkin bir şekilde düzenlenmesine intiyaç duyulmaktadır. Buna bağlı olarak ekipmanların kapasite kullanım oranları azalmakta ve bu oranı arttırmak için yeni faaliyetlere ihtiyaç duyulmaktadır.

\subsection{Gelecek Durum Haritasının Çizimi}

Üretim bölümü, değer akışı haritalama ile atölye gerçeklerine dayanarak kendisine bir yön ve plan oluşturmuştur. Bunun için mevcut durum haritasının verileri göz önünde bulundurulmuş ve oluşturulacak çözüm için süreçte yapılacak değişiklikler belirlenmiştir. Akışın hızını belirleyen tempo süreci (pacemaker process) için müşteriye en yakın olan montaj hattı süreci seçilmiştir. XYZ yönetimi değer akışının mevcut durumunu değerlendirerek, montaj hattının model değişiminden en az etkilenecek şekilde yeniden düzenlenmesi gerektiği sonucuna varmıştır. Bunun için iki farklı model olan A ve B model arka koltukların, ortak bir hatta üretilmesine karar verilmiştir. Gelecek durum haritasına ulaşmak için yapılacak iyileştirmeler modellere ilişkin üretim miktarındaki değişiklikleri kontrol altına alma ve kalite güvencesini sağlama başlıkları altında değerlendirilmiştir. 
Şekil 3. XZY Montaj Hattı Mevcut Durumu

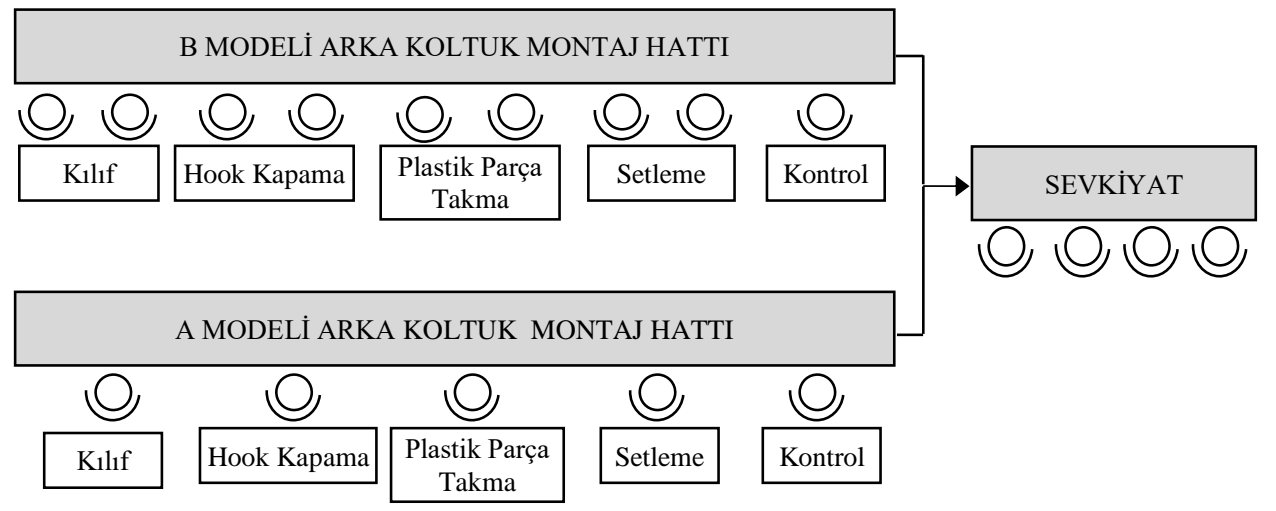

Arka koltuk modellerinin üretim miktarındaki değişiklikleri kontrol altına almak için A ve B model koltuk üretiminde ortak montaj hattına geçilmesi, ekipmanların düzenlenmesi ve üretim için sadece telemail sistemi bilgisinin kullanılması planlanmıştır. Modelin miktarındaki değişikliklerden etkilenmemek için $A$ ve $B$ model (Şekil 3) arka koltuk montaj hatları birleştirilerek, ortak montaj hattına geçilmiştir (Şekil 4). Ayrı hatlarda üretilen toplam 700 sette, A ve B modellerinin her birinin payları \% 50 iken, ABC işletmesi \% 40'a \% 60 oranında değişiklik yaptığında XYZ'de takt zamanının ayarlanması, çalışan sayısı, çalışan iş dağıımı, hat liderinin ve diğer çalışanların eğitimi vb. değişikliklerin yapılması gerekmekte ve bu durum israfa neden olmaktadır. XYZ ortak hat üretimi için her modele ait bir subline hat oluşturmuştur (Şekil 4). Subline hat, modele ait işleri kapsayan yardımcı bir hat olarak çalışmaya başlamıştır. Bununla birlikte toplam üretim miktarı olan 700 adet değiştirilmedikçe montaj hattında değişiklik yapmaya gerek kalmamıştır. Sadece \% $20^{\prime}$ lik değişiklik, subline hatlarda ekipman ve diğer ayarlamaları yapmak için yeterli olmuştur. Subline hatları, ön hazırlık zamanlarını üstlenerek montaj hattını desteklemiştir. Yapılacak düzenlemelerden montaj hattının tamamının etkilenmesi önlenmiştir. Kısaca üretim miktarı sabitken üretilecek model miktarındaki değişiklikler, işin \%20'lik kısmı olan subline hatlarda yapılmış ve model miktarındaki değişimden montaj hattının en az etkilenmesi sağlanmıştır.

Şekil 4. XZY Montaj Hattı Gelecek Durum

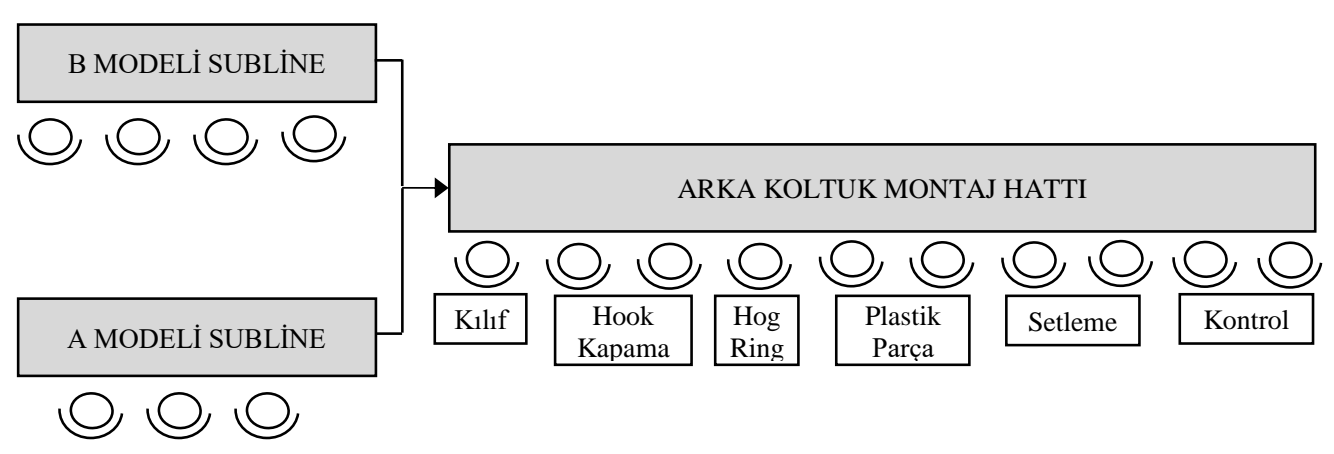

Üretim ve sevkiyat için sadece telemail bilgisi kullanılmaya başlanmıştır. Mevcut durumda, XYZ işletmesi üretim için ALC bilgisi kullanmaktadır. ALC bilgisi, müşteri işletme olan ABC'nin üretim hatlarında üretilen ürünün bilgisini $X Y Z$ işletmesine iletmekte ve $X Y Z$ müşterisi $A B C$ ile aynı ürünleri aynı anda üretmektedir. Ancak XYZ işletmesinin ALC sistemi ile aldığı sıralı bilgi, $A B C$ 'nin üretim süreçleri olan presleme, kaynak ve boya aşamalarında kalite sorunları, yapılan hatalar vb. nedenlerle meydana gelen değişikliklerden etkilenerek yer değiştirebilmektedir. Buna karşılık XYZ, ALC ile aldığı üretim bilgisine uygun olarak ürünü tamamlamakta ve sevkiyatta sevk bilgisi gelene kadar bekletmektedir. Bu durum XYZ'nin elinde daha fazla bitmiş ürün stoku bulundurmasına neden olmaktadır. $X Y Z$, stoku önlemek, fabrikadaki bilgi akışını standartlaştırmak ve her şeyden önemlisi müşterinin talebine uygun olarak fabrika üretimini çekme sistemine 
göre yeniden ayarlamak için üretim bilgisinde ALC sisteminin kullanımına son vermiş ve sadece telemail bilgisini kullanmaya başlamıştır. $X Y Z, A L C$ sistemi ile $A B C$ işletmesinin üretim hattındaki üretim bilgisini alırken, telemail ile $A B C$ işletmesinin montaj hattı öncesindeki üretim bilgisini almaya başlamıştır. Telemail bilgisinin, montaj hattının ön kısmında oluşturulan, montaj hattında üretimi yapılacak ürün parçalarının bulunduğu Rock Kontrol sisteme gelmesi sağlanmıştır. XYZ işletmesi, ABC işletmesinin montaj hattında üretmeyi ve müşterisine sevkiyatını planladığı ürünleri, üretmeye başlamıştır. Üretim bilgisinde fazla değişiklik olmadığından ve stok olarak fazla bitmiş ürüne gerek kalmadığından sevkiyat kısmı kaldırılarak bitmiş ürünler doğrudan $A B C^{\prime} y e$ gönderilmiştir. Bu uygulama ile sevkiyat çalışanları montaj hattına ilave edilmiştir. XYZ değer akış haritasında elektronik bilgi akışının gösterilmesinde bilgisayar, yazıcı vb. kullanılarak daha anlaşıır hale getirilmiştir. Ekipmanlar yaygınlaştırılarak kapasite oranları standartlaştırılmıştır. Ekipmanlar, hatlara uygun olarak dağıtılmış ve bir düzen dâhilinde çalıştırılmaya devam edilmiştir. Ekipmanların yerleri ve kullanıcıları genel olarak aynı olduğundan kapasite miktarındaki değişiklikler önlenmiş̧ir. XYZ işletmesinin gelecek durum haritası Şekil 5'te gösterilmiştir.

Şekil 5. XYZ İşletmesi Gelecek Durum Haritası

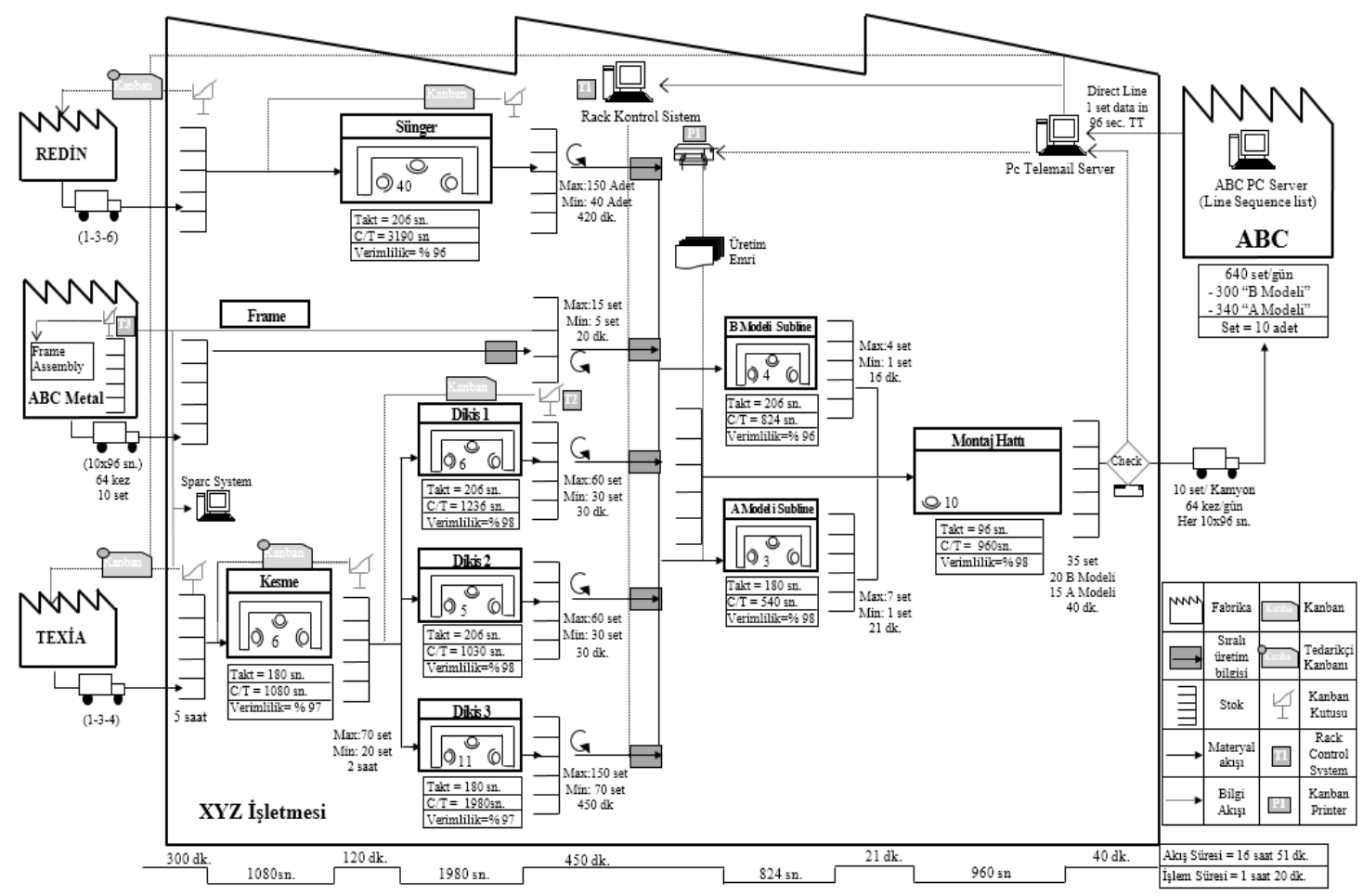

Kalite güvencesinin sağlanması ve kalite problemlerinin önlenmesi için XYZ montaj hattında oluşturulan yeni çalışma düzeninde;

- Çalışanların dışsal operasyonları azaltıldı,

- Parça eksikliği veya yanlış parça montajı engellendi,

- Yapılması zor olan işlerde iyileştirme yapılarak daha kolay yapılması sağlandı,

- Koltuk montajındaki sıkım torkları kontrol altına alındı,

- Hatalar ve hat duruş zamanı azaltıldı,

- Alan tasarrufu elde edildi,

- Üretim kapasitesi arttırıldı,

- Hat liderinin, üretim hattının içinde olması sağlandı.

Gelecek durum haritasında yapılan işin ve iyileştirmenin büyük kısmı, parça sunumu bölgesinde yapılmıştır. XYZ, üretimdeki kusurların önemli kısmının, parça seçiminde üçten fazla karar alınan süreçlerde ortaya çıktığını belirlemiştir. Mevcut durumda montaj hattı çalışanı, hem ürün kanban bilgisine göre montaj 
hattının yanında bulunan ürün parçalarını almakta hem de bu parçaların montajını yapmaktadır. Takt zamanın kısalığı nedeniyle çalışanın ürün kanban bilgisine uygun parça seçmek için az zamanı bulunmaktadır. Bu uygulamada çalışan, ihtiyaç olan malzemeyi eksik veya yanlış alabilmektedir. Ortak hat oluşturulduğunda ise çalışanın etrafındaki ürün parçalarının bulunduğu raflar kaldırılarak montaj hattı öncesinde bir alana toplanmıştır. Parça seçme kararları, montaj hattı çalışanlarından alınmış, çalışanların dışsal operasyonları azaltılmış ve montaj hattı öncesindeki alana taşınmıştır. ABC üretim isteklerini sırasıyla telemail yoluyla gelen ve jundate olarak adlandırılan sıralanmış malzeme listesini Subline hatlarının gerisindeki rafların toplandığı alanda yer alan Rack kontrol sistemine bildirdiğinde, ilgili ürün bilgisini içeren kanban çıktısı alınmakta ve aynı anda görsel ikaz sistemi ile ürüne ait tüm parçaların ışığı yanmaya başlamaktadır. Çalışan, ürün için gerekli parçaları alıp ürün ikaz ışığını kapatmakta ve olası eksiklik veya yanlışlıklar önlenmektedir. Ürüne ait parçalar, telemailden gelen kanban çıktısı ile birlikte işlem sırasına göre yerleştirilmiştir, tüm parçalar bir kutuya konulup çalışan için set haline getirilmiş ve böylece hat çalışanın karar verme sayısı azaltılmıştır. Malzeme taşıyanlar, bu kutuları alarak montaj hattına bırakmaya başlamışır. Montaj hattının tedarik sistemi, set temeli üzerine oluşturulmuş, arka koltuk montajında intiyaç duyulan tüm malzemeler aynı anda getirilmiş ve çalışanlar bu malzemeleri kullanmıştır. Mevcut durumda çalışanın, hem ürünün kanban bilgilerini kontrol ederek parça alması hemde montajını yapması önlenmiştir. Böylece olası hatalar engellenmiş ve çalışanın dışsal operasyonları azaltılarak işine odaklanması sağlanmıştır. Montaj hattının alt kısmında oluşturulan mekanizma ile montaj hattının en sonundan başlayarak montajı yapılan malzemelerin boş kutularının geri dönüşü sağlanmışır. Kutularda kalan malzeme olması eksik işlem yapıldığını göstermekte, hata hemen fark edilip hat akışı durdurulmakta ve eksik montaj tamamlanmaktadır.

Yapılması zor olan işlerde iyileştirmeler yapılmış ve hatalar azaltılmıştır. Mevcut durumda, montaj hattında koltuk dik pozisyonda iken çalışanlar bazı işlemleri yapmakta zorlanmaktadır. Gelecek durumda ise belirli bir noktadan sonra çalışanların işlerinin kolaylaştırılması amacıyla "Yamagata" olarak adlandırılan makina ile koltuk ters döndürülerek çalışanların işlemlerini daha rahat yapması sağlanmıştır. Yamagata sistemi ile çalışanın montaj işlemleri kolaylaştırılmış, hata miktarı ve nedenleri azaltılmıştır. Ayrıca mevcut durumda, kalıbı süngere giydirme işleminde zorlanılmaktadır. Gelecek durumda ise bu işlem bir pres kullanılarak yapılmıştır. Bu işlemler ile çalışanlara ergonomik kolaylıklar sağlanmıştır.

Koltuk montajındaki sıkım torkları kontrol altına alınmıştır. Mevcut durumda, montaj hattının önemli işlemlerinden biri koltuğun oturakla sırt kısmını birbirine bağlayan cıvatalar, emniyet kemeri koltuk setleme cıvatalarının sıkılması havalı tabanca ile yapılmaktadır. Havalı tabancalar torku tutturamadığında veya çalışan cıvataları tam sıkmadığında bile işlem tamamlanmış olarak görülebilmektedir. Ayrıca havalı tabancalarda cıvatanın diş kapması, sıyırma, çapak vb. hatalar meydana gelmektedir. Gelecek durumda, elektrikli sıkma tabancalar ile bu işlemler yapılmaya başlanmışır. Elektrikli tabancalar, tork ve açıyı hesap ederek sıkma işlemini yapmaktadır. İstenen sıkma işlemi çapak, yetersiz sıkma vb. nedenlerle olmadığında kendi andon ikaz lambası yanmakta ve işlem tamamlanmadığında ortak hat durmaktadır. Hat lideri gelmekte ve sorun çözüldüğünde üretim devam etmektedir. Böylece airbag sıkma hatası vb. müşteriye ulaşması ve bunun neden olabileceği önemli sorunların önüne geçilmiştir.

Mevcut durumdan, gelecek duruma geçildikten sonra montaj hattındaki hat duruş zamanında iyileştirme sağlanmıştır. Mevcut durumda hat duruş zamanı, çalışanların tek model koltuk üretmesi nedeniyle işlerinde uzmanlaşmış olması ve uzun süre mevcut durumun hatalarının giderilmiş olmasından dolayı hat duruş zamanı 25 dakikadır. Ortak hatta geçilmesi ile birlikte montaj hattındaki hat duruş zamanı 60 dakikaya ulaşmıştır. Çalışanların eğitimi, eksikliklerin giderilmesi, gerekli görsel kontrol yöntemleri vb. ile bu süre gelecek durumun gerçekleşmesinden sonraki süreçte 10 dakikaya indirilmiştir. Mevcut durumda, A modeli montaj hattında 53 adet ve B modeli montaj hattında 38 adet toplamda 91 hata yapılmıştır. Gelecek durum haritası gerçekleştirildikten sonra ortak hatta geçilmesi ve yapılan iyileştirmeler sonrasında ise toplam hata sayısı 28'e indirilmiştir. Gelecek durum haritasındaki ortak montaj hattına ve yapılan iyileştirmelere, çalışanların uyumunun artması ile bu sayının azalacağı beklenmektedir.

Gelecek durum haritasında alan tasarrufu sağlanmıştır. Mevcut durum haritasında, $A$ ve $B$ arka koltuk model montaj hattı yaklaşık olarak 10 metre genişliğinde ve 15 metre uzunluğunda olup toplam $150 \mathrm{~m}^{2}$ alanda yer almıştır. Gelecek durum haritasında ortak montaj hattı, 5 metre genişliğinde 25 metre 
uzunluğunda olup toplam $125 \mathrm{~m}^{2}$ alana sahiptir. Mevcut durumda, A ve B modeli montaj hatlarında, çalışanların yanlarında bulunan montaj malzemelerinin olduğu $25 \mathrm{~m}^{2}$ alandan tasarruf edilmiştir. Ayrıca sevkiyat için hazır bekleyen bitmiş ürün miktarı 70 setten 35 sete indiğinden bitmiş ürünlerin bulunduğu alanda $50 \mathrm{~m}^{2}$ alan kazanılmıştır.

Gelecek durum haritası gerçekleştiğinde, üretim kapasitesinde artış olmuştur. Mevcut durum haritasında üretim kapasitesi günlük 750 set olurken, gelecek durum haritası gerçekleştikten sonra üretim kapasitesi 850 sete ulaşmıştır. Yalın organizasyon XYZ, müşteri talep etmedikçe bu sayıya ulaşmayacak ve talebe uygun olarak takt zamanına göre üretim yapacaktır. Ayrıca ortak hatta geçilmesi ile çalışanlara, hat liderinin desteği artırımıştır. Mevcut durumda, hat lideri her zaman hat içerisinde olamamaktadır. Ortak montaj hattının oluşturulmasıyla hat liderinin, hattın içinde olması garanti altına alınmıştır. Ayrıca arka koltuk üretiminin akış süresi 19 dakika azaltılmış (Tablo 1) ve değer katan işlem süresinin miktarı arttırılmıştır (Şekil 5). Özellikle sevkiyat biriminin kaldırılması ve montaj hattı stok miktarının azaltılmasının bu sürenin iyileştirilmesine katkısı olmuştur. Mevcut durumda müşteri talep miktarı olan 700 set, gelecek durumda 640 set olarak talep edilmiştir. Gelecek durumda, müşteri talep miktarındaki değişme göre takt zamanı arttırılarak üretim hızı azaltılmıştır. Mevcut durumda olduğu gibi üretim talep miktarı arttığında veya takt zamanı azaltıldığında akış süresindeki iyileştirmenin daha fazla olacağı belirlenmiştir. Mevcut durum haritası ile gelecek durum haritası kıyaslandığında gerçekleştirilen iyileştirmeler Tablo 1'de sunulmuştur.

Tablo 1. XYZ İşletmesi Arka Koltuk Montaj Hattı Mevcut ve Gelecek Durum Karşılaştırması

\begin{tabular}{cccccccc}
\hline & $\begin{array}{c}\text { Üretim } \\
\text { Kapasitesi }\end{array}$ & $\begin{array}{c}\text { Akış } \\
\text { Süresi }\end{array}$ & $\begin{array}{c}\text { Hat Duruş } \\
\text { Zamanı }\end{array}$ & $\begin{array}{c}\text { Hata } \\
\text { Sayısı }\end{array}$ & $\begin{array}{c}\text { Çalışan } \\
\text { Sayısı }\end{array}$ & $\begin{array}{c}\text { Alan } \\
\text { Tasarrufu }\end{array}$ & $\begin{array}{c}\text { Bitmiş Ürün } \\
\text { Stok Miktarı }\end{array}$ \\
\hline $\begin{array}{c}\text { Mevcut } \\
\text { Durum Haritası }\end{array}$ & 750 & $\begin{array}{c}17 \mathrm{saat} \\
10 \mathrm{dk} .\end{array}$ & $25 \mathrm{dk}$. & 91 & 18 & & $70 \mathrm{set}$ \\
\hline Gelecek & 850 & $\begin{array}{c}16 \mathrm{saat} \\
51 \mathrm{dk} .\end{array}$ & $10 \mathrm{dk}$. & 28 & 17 & $75 \mathrm{~m}^{2}$ & $35 \mathrm{set}$ \\
Durum Haritası & & $51 \mathrm{n}$ & & & & & \\
\hline
\end{tabular}

Gelecek durum haritasını gerçekleştirmeye yönelik iyileştirmeleri yapabilmek için XYZ fabrikasında tüm bölümler yapılacak işlere uygun olarak kendi planlarını oluşturmuştur. Üretim mühendisliği, gelecek durum haritasına uygun olarak tüm fabrikanın yerleşim planını oluşturduktan sonra bunların nasıl uygulanacağının alt planlarını yapmıştır. Örneğin, arka koltuk montaj hattının kurulumunda ne zaman eski hatlar kaldırılarak yeni altyapının oluşturulacağı (elektrik, hava, buhar vb.), yeni ekipmanların hangi tedarikçilerden ne zaman alınacağı, denemelerin ne zaman yapılacağı ve üretime teslim edileceği belirlenmiştir. Üretim bölümü ise plan aşamasında, planın kendi şartlarına uygunluğunu kontrol ettikten sonra yeni hatlarda çalışma standartlarını hazırlamak için planını yapmıştır. Bu planda, kimler ne zaman eğitim alacak, yardımcı el aletleri ne olacak, ne zaman kimden tedarik edilecek, denemeler ne zaman yapılacak, seri üretime ne zaman geçilecek, kaliteyi sağlamak için hangi kontrol noktaları belirlenecek vb. faaliyetler yer almıştır. Tüm bu planların kendi içlerinde de alt planları oluşturulmuştur. Ayrıca kalite, bakım, üretim kontrol vb. diğer bölümlerde kendi planlarını ve detaylı alt planlarını yapmıştır. Sonuç olarak gelecek durum haritasını gerçekleştirmek üzere farklı yalın araçlar kullanılarak ve problemler çözümlenerek bir plan dâhilinde iyileştirmeler yapılmıştır.

\section{Sonuç ve Öneriler}

Işletmeler, müşteri beklenti ve ihtiyaçlarını karşılayacak üstün değer önerisi sunduğunda, rakiplerinin önüne geçmektedir. Bu üstün değer önerisi maliyet üstünlüğü, kalite, teknoloji, hız, yenilik ve diğer alanlarda olabilmektedir. Müşterinin değer tanımını anlayabilmek, işletmenin faaliyetlerinde yol gösterici olmaktadır. Değer akışı haritalama, değerin tanımlanmasına, işletmenin tüm süreçlerinde değer katmayan faaliyetlerin ortadan kaldırılmasına dolayısıyla faaliyetlerin uyum içerisinde gerçekleştirildiği akışın sağlanmasında ve bu 
faaliyetlerin en az kaynak kullanımı ile müşteri talebine uygun hızla gerçekleştirilmesinde kullanılan görsel bir yönetim aracıdır. Yalın organizasyon araçlarından olan değer akışı haritalamanın uygulandığı otomotiv sektöründeki bu vaka çalışmasında, çalışan sayısının azaltıldığı, alan tasarrufu sağlandığı, hataların azaltıldığı, üretim kapasitesinin arttırıldı̆̆ı, hat duruş zamanının azaltıldığı, akış süresinin kısaltıldığı, bitmiş ürün stokunun azaltıldığı tespit edilmiştir. Elde edilen sonuçların, literatür ile uyumlu olduğu görülmüştür (Seth ve Gupta, 2005; Matt, 2008; Grewal, 2008; Lasa vd., 2008; Singh ve Sharma, 2009; Vinodh vd., 2010; Singh vd., 2011; Wang vd., 2015). Değer akışı haritalama uygulamasının, süreçlerin iyileştirilmesine önemli katkısının olduğu belirlenmiştir. XYZ işletmesi açısından, arka koltuk montaj hattı birleştirilerek önemli kazançlar elde edilmiştir. Sonraki süreçte ön koltuk montaj hattının birleştirilmesi planlanmakta ve böylece sürekli iyileştirilmeler yaparak daha rekabetçi olmaya çalışılmaktadır.

Araştırmanın tek işletmede yapılmış olması nedeniyle sonuçların genelleştirilememesi, çalışmanın en önemli kısıtlaması olmuştur. Ayrıca işletme bilgilerinin güvenliği için araştırmayı etkilemeyecek şekilde bazı verilerde kısmi değişiklik yapılmıştır. Akademisyenlerin sonraki çalışmalarda değer akışı haritalamayı farklı seviyelerde uygulamaları veya farklı ülkelerin yalın işletmelerini, kültürel açıdan ele alarak incelemelerinin faydalı olabilecekleri değerlendirilmiştir. İşletmelerin, yalın olmanın faydalarını dikkate alarak bu yönde çaba sarf ettiği görülmektedir. Ancak yalın olmak, Toyota ve diğer yalın işletmelerin kullandığı araçları taklit etmek değildir (Liker, 2005). İşletmelerin, yalın araçları uyguluyor olmaları onları yalın yapmamaktadır (Seth ve Gupta, 2005). Japon kültürü üzerine kurulu olan yalın üretim felsefesi ve araçlarının bir bütün olarak uygulandığında istenilen sonuçlara ulaşılabileceği unutulmamalı ve işletmelerin yalın olmaya çalışırken mevcut koşullar ve kültürlerini dikkate alarak ilerlemeleri önerilmektedir. Değer akışı haritalama uygulaması ile mevcut duruma ilişkin değer akışının görülebildiği, israf kaynaklarını tespit edilebildiği, iyileştirme alanlarının belirlendiği, farklı yalın tekniklerle birlikte süreçlerin iyileştirilebildiği ve böylece işletmelere yalın olma ve rekabet avantajı elde etme yolunda önemli kazanımlar sağlayabileceği değerlendirilmiştir.

\section{Beyan ve Açıklamalar (Disclosure Statements)}

1. Bu çalışmanın yazarları, araştırma ve yayın etiği ilkelerine uyduklarını kabul etmektedirler (The authors of this article are admitted that they complied with the principles of research and publication ethics).

2. Yazarlar tarafından herhangi bir çıkar çatışması beyan edilmemiştir (No potential conflict of interest was reported by the authors).

3. Bu çalışma, intihal tarama programı kullanılarak intihal taramasından geçirilmiştir (This article was screened for potential plagiarism using a plagiarism screening program).

\section{Son Notlar}

1. Bu çalışma, Hakan Aydın tarafından hazırlanan "Yalın Üretim Sistemi, Değer Akış Haritalama Yöntemi ve Çalışanlar Üzerine Etkileri" başlıklı yüksek lisans tezinden üretilmiş, 02-04 Mayıs 2019 tarihlerinde düzenlenen 18. Uluslararası işletmecilik Kongresi'nde sunulmuş bildirinin, genişletilmiş ve yeniden düzenlenmiş halidir.

\section{Kaynaklar}

Abdulmalek, F. A., \& Rajgopal, J. (2007). Analyzing the benefits of lean manufacturing and value stream mapping via simulation: A process sector case study. International Journal of Production Economics, 107(1), 223-236.

Acar, N. (2003). Tam zamanında üretim. Milli Prodüktivite Merkezi Yayınları.

Aziz, Z., Qasim, R. M., \& Wajdi, S. (2017). Improving productivity of road surfacing operations using value stream mapping and discrete event simulation. Construction Innovation, 17(3), 294-323.

Dinis-Carvalho, J., Guimaraes, L., Sousa, R. M., \& Leao, C. P. (2018). Waste identification diagram and value stream mapping: A comparative analysis. International Journal of Lean Six Sigma, 17(1), 760-77. 
Emiliani, M. L., \& Stec, D. J. (2004). Using value-stream maps to improve leadership. Leadership \& Organization Development Journal, 25(8), 622-645.

Grewal, C. (2008). An initiative to implement lean manufacturing using value stream mapping in a small company. International Journal of Manufacturing Technology and Management, 15(3/4), 404-417.

Hirano, H. (1995). 5 pillars of the visual workplace: The sourcebook for 5 S implementation. NewYork: Productivity Press.

Hines, P., \& Rich, N. (1997). The seven value stream mapping tools. International Journal of Operations \& Production Management, 17(1), 46-64.

Hines, P., Rich, N., \& Esain, A. (1998). Creating a lean supplier network: A distribution industry case. European Journal of Purchasing \& Supply Management, 4(4), 235-246.

http://www.iso500.org.tr/500-buyuk-sanayi-kurulusu/2017/

Jones, D., \& Womack, J. (2002). Bütünü görmek: Genişletilmiş değer akışı haritalama. Yalın Enstitü Derneği. Version 1(0).

Imai, M. (1994). Kaizen, Japonya'nın rekabetteki başarısının anahtarı. İstanbul. BRiSA.

Imai, M. (2014). Gemba kaizen: Sürekli iyileştirmeye sağduyulu bir yaklaşım. Oygur Yamak (çev.). Nobel Akademi.

Jasti, N. V. K., Kota, S., \& Sangwan, K. S. (2019). An application of value stream mapping in auto-ancillary industry: A case study. The TQM Journal, 32(1), 162-182.

Kitazuka, E. R., \& Moretti, C. (2012). Jidoka. Toyota By Toyota: Reflections from the inside leaders on the techniques that revolutionized the industry. Obara, S., \& Wilburn, D. (Ed.). CRC Press.

Lacerda, A. P., Xambre, A. R., \& Alvelos, H. M. (2016). Applying value stream mapping to eliminate waste: A case study of an original equipment manufacturer for the automotive industry. International Journal of Production Research, 54(6), 1708-1720.

Lasa, S. I., Ochoa Laburu, C., \& de Castro Vila, R. (2008). An evaluation of the value stream mapping tool. Business Process Management Journal, 14(1), 39-52.

Lian, Y. H., \& Van Landeghem, H. (2007). Analysing the effects of lean manufacturing using a value stream mappingbased simulation generator. International Journal of Production Research, 45(13), 3037-3058.

Liker, J. (2005). Toyota tarzı, 14 yönetim ilkesi. Ü. Şensoy (çev.). Orhan Holding Yayınları.

Lobo, C. V. F., Damasceno Calado, R., \& Dalvo Pereira da Conceição, R. (2018). Evaluation of value stream mapping (vsm) applicability to the oil and gas chain processes. International Journal of Lean Six Sigma, 5(1), 89-116.

Manos, T. (2006). Value stream mapping an introduction. Quality Progress, 39(6), 64-69.

Marchwinski, C., \& Shook, J. (2007). Yalın kavramlar sözlüğü. Ayşe Soydan ve Regaip Baran (çev.). İstanbul: Yalın Enstitü Yayınları.

Matt, D. T. (2008). Template based production system design. Journal of Manufacturing Technology Management, 19(7), 783-797.

McCarthy, D., \& Rich, N. (2015). Lean TPM: A blueprint for change. Butterworth-Heinemann.

Monden, Y. (2012). Toyota production system: An integrated approach to just-in-time. CRC Press.

Morgan, J. M., \& Liker, J. K. (2007). Toyota ürün geliştirme sistemi. Aysel Yılmaz (çev.). İstanbul: Farba Yayınları.

Ohno, T. (1996). Toyota ruhu. Canan Feyyat (çev.). İstanbul: Scala Yayıncılık.

Okur, A. S. (1997). Yalın üretim: 2000'li yıllara doğru Türkiye sanayii için yapılanma modeli. Söz Yayın.

Özçelikel, H. (1994). Bir personel yöneticisinin gözüyle: Japon yönetim sistemleri. MESS Eğitim Vakfı.

Rosenbaum, S., Toledo, M., \& González, V. (2014). Improving environmental and production performance in construction projects using value-stream mapping: Case study. Journal of Construction Engineering and Management, 140(2), 04013045:1-10

Rother, M., \& Shook, J. (1999). Görmeyi öğrenmek: Değer yaratmak ve israfı ortadan kaldırmak için değer akışı haritalama. İstanbul: Yalın Enstitü Yayınları.

Schmidtke, D., Heiser, U., \& Hinrichsen, O. (2014). A Simulation-enhanced value stream mapping approach for optimisation of complex production environments. International Journal of Production Research, 52(20), 61466160.

Seth, D., \& Gupta, V. (2005). Application of value stream mapping for lean operations and cycle time reduction: An Indian case study. Production Planning \& Control, 16(1), 44-59.

Shingo, S. (1985). A revulation in manufacturing: The SMED system. Andrew P. Dillon (çev.) Cambrige: Productivity Press. 
Singh, B., \& Sharma, S. K. (2009). Value stream mapping as a versatile tool for lean implementation: An Indian case study of a manufacturing firm. Measuring Business Excellence, 13(3), 58-68.

Singh, B., Garg, S. K., \& Sharma, S. K. (2011). Value stream mapping: Literature review and implications for Indian industry. The International Journal of Advanced Manufacturing Technology, 53, 799-809.

Singh, H., \& Singh, A. (2013). Application of lean manufacturing using value stream mapping in an auto-parts manufacturing unit. Journal of Advances in Management Research, 10(1), 72-84.

Sunk, A., Kuhlang, P., Edtmayr, T., \& Sihn, W. (2017). Developments of traditional value stream mapping to enhance personal and organisational system and methods competencies. International Journal of Production Research, 55(13), 3732-3746.

Suzaki, K. (2005). Imalatta mükemmellik yolu: Sürekli iyileştirme teknikleri. İstanbul. Otoyol Sanayi A.Ş.

Tapping, D., \& Shuker, T. (2003). Value stream management: Eight steps to planning, mapping, and sustaining lean improvements. Productivity Press.

Taylor, D. H. (2005). Value chain analysis: An approach to supply chain improvement in agri-food chains. International Journal of Physical Distribution \& Logistics Management, 35(10), 744-761.

Toyota Otomotiv Sanayi, (2006). Toyota üretim sistemi (standart işler ve kaizen) 2004 revizyonu. Toyota Otomotiv Sanayi Türkiye A.Ş. İnsan Kaynakları Geliştirme Bölümü.

Türkiye İhracatçılar Meclisi, (2019). İhracat 2019 raporu: Yeni vizyon, yeni yol haritası.

Vinodh, S., Arvind, K. R., \& Somanaathan, M. (2010). Application of value stream mapping in an Indian camshaft manufacturing organisation. Journal of Manufacturing Technology Management, 21(7), 888-900.

Wang, T. K., Yang, T., Yang, C. Y., \& Chan, F. T. S. (2015). Lean principles and simulation optimization for emergency department layout design. Industrial Management \& Data Systems, 115(4), 678-699.

Womack, J. P., Jones, D. T., \& Roos, D. (1990). Machine that changed the world. Simon and Schuster.

Womack, J. P., \& Jones, D. T. (2003). Lean thinking: Banish waste and create wealth in your corporation. Free Press.

Womack, J., \& Jones, D. (2006). Yalın çözümler. İstanbul, Petrol Ofisi. 
This Page Intentionally Left Blank 